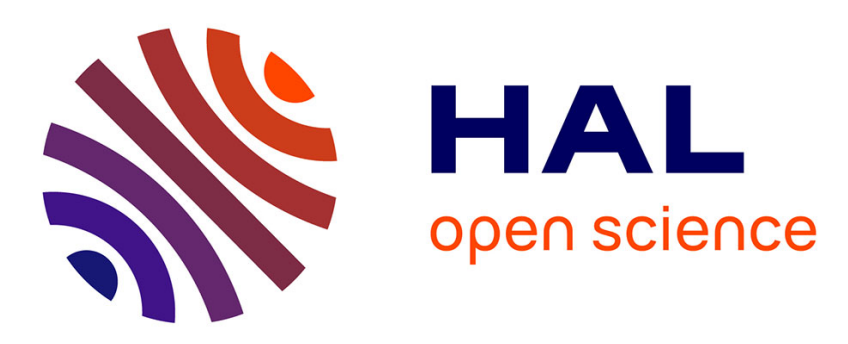

\title{
A joint use of Raman and infrared spectroscopies for the identification of natural organic media used in ancient varnishes
}

Céline Daher, Céline Paris, Anne-Solenn Le Hô, Ludovic Bellot-Gurlet, Jean-Philippe Echard

\section{To cite this version:}

Céline Daher, Céline Paris, Anne-Solenn Le Hô, Ludovic Bellot-Gurlet, Jean-Philippe Echard. A joint use of Raman and infrared spectroscopies for the identification of natural organic media used in ancient varnishes. Journal of Raman Spectroscopy, 2010, 41 (11), pp.1204-1209. 10.1002/jrs.2693 . hal-00864287

\section{HAL Id: hal-00864287 \\ https://hal.science/hal-00864287}

Submitted on 20 Sep 2013

HAL is a multi-disciplinary open access archive for the deposit and dissemination of scientific research documents, whether they are published or not. The documents may come from teaching and research institutions in France or abroad, or from public or private research centers.
L'archive ouverte pluridisciplinaire HAL, est destinée au dépôt et à la diffusion de documents scientifiques de niveau recherche, publiés ou non, émanant des établissements d'enseignement et de recherche français ou étrangers, des laboratoires publics ou privés. 


\title{
A joint use of Raman and infrared spectroscopies for the identification of natural organic media used in ancient varnishes
}

\author{
Céline Daher, ${ }^{a}$ Céline Paris, ${ }^{a}$ Anne-Solenn Le Hô, ${ }^{b}$ \\ Ludovic Bellot-Gurlet, ${ }^{a}$ and Jean Philippe Échard, ${ }^{c}$
}

\begin{abstract}
Various natural organic film-making media from several chemical families have been used as varnishes. An improvement in the identification of these materials by the combination of Raman and infrared spectroscopies is here presented. Fourteen unaged reference samples representative of resins, glues, gums and oils were analyzed. FT-Raman and IR spectra were all compared in order to discriminate the different classes of organic media by considering their spectroscopic features. It led to a flowchart for material discrimination based on simple, notable and specific criteria. It appears that the different families (gums, glues, oils and resins) and subfamilies (di/triterpenoids resins) are easily differentiated thanks to their specific structural composition. However, discerning between compounds from a same subgroup, for example diterpenoid resins, could be ambiguous because the spectra depend on the sample aspect, age and degradations.
\end{abstract}

Keywords: FT-Raman, infrared, natural organic media, terpenic resins, material discrimination - DOI: 10.1002/jrs.2693

\section{Introduction}

The organic substances possibly used as ancient varnishing materials are quite well known, and seem to be comparable for musical instruments and for furniture ${ }^{[1,2]}$. They are made of natural organic components such as resins, oils, waxes, glues or gums with, in some cases, inorganic additives. Proteinaceous materials (egg, animal glues,...) and polysaccharides (gums) may have been used, applied first onto the wood, as sealers or basecoats. Glues are composed of collagen derivatives, an extra cellular protein which is the main component of cartilage, ligaments, tendons, bone and skin $\left.{ }^{32} 2000\right]$. The major amino acids and derivatives found in collagen are glycine, proline and hydroxylysine. Gums exudates from trees and are soluble in water. The most commonly used material in this family is arabic gum. It is a complex mixture of saccharides and few glycoproteins whose major component is arabic acid, a polymer of galactose, arabinose, rhamnose and D-glucuronic acid ${ }^{[4]}$. The one (or more) upper coats of varnish may contain (alone or in mixture) natural resins and drying oils, which protect the wood and may also enhance its visual aspect. Natural resins exude from plants or are insects' excretions. Vegetal resins are often complex mixtures of components based on different types of terpenoid skeletons and are not soluble in water. They are made of di- or triterpenoids in addition to a liquid part made of mono- and sesquiterpenoids [5]. Insect resins are mixtures of esters of fatty acids, acids derivatives of sesquiterpenes, wax and anthraquinone dyes ${ }^{[5]}$. Drying oils contain polyunsaturated fatty acids (such as linolenic acid) which play an important role in their oxidation ${ }^{[6]}$. Walnut, poppyseed and particularly linseed oils are the most commonly used and their chemical composition differs only in the relative concentration of the same twenty-odd fatty acids ${ }^{[5]}$.

These organic materials may be identified by various analytical methods. In the field of conservation science and preservation of cultural heritage artefacts, the most widely employed techniques are gas chromatography coupled with mass spectrometry ${ }^{[7-12]}$, possibly preceded by pyrolysis to study the polymerized components ${ }^{[13-15]}$ and infrared spectroscopy $\left({ }^{[2,16-20]}\right.$ for analyses of paintings and varnish materials).

Nevertheless, chromatographic techniques require the sample's destruction and can not document the organization of heterogeneous samples. Moreover, they induce specific and long preparations that may differ depending on the sample's chemical family. Besides, vibrational spectroscopy constitutes a technique of choice because it does not require any sampling preparation or destruction. Indeed, working through a microscope for Raman analyses, or by squeezing the sample in a diamond cell for infrared (IR) analyses

a Laboratoire de Dynamique, Interactions et Réactivité (LADIR), UMR 7075 CNRS and Université Pierre et Marie Curie-Paris 6 (UPMC), 2 rue Henry Dunant, 94320 Thiais (France), cel.daher@gmail.com, celine.paris@upmc.fr, ludovic.bellot-gurlet@upmc.fr

b Centre de Recherche et de Restauration des Musées de France C2RMF, UMR 171 CNRS and Ministère de la Culture et de la Communication, Palais du Louvre-Porte des Lions, 14 quai François Mitterrand, 75001 Paris (France), anne-solenn.leho@culture.gouv.fr

c Laboratoire de Recherche et de Restauration, Musée de la Musique, Cité de la Musique, 221 avenue Jean Jaurès, 75019 Paris (France), jpechard@cite-musique.fr 
keeps the sample intact or available for further analyses. Furthermore, they allow the investigation of the spatial composition and organization of a varnish at microscales. However, IR alone may not be able to allow a fine discrimination between some materials within a same family ${ }^{[7,8,20-22]}$.

Previous studies using Raman or FT-Raman spectroscopy were performed on reference materials to build a library of reference spectra $[3,4,23]$, on archaeological objects ${ }^{[24-26]}$, and on the ageing and degradation of natural resins ${ }^{[27,28]}$. However, the experimental conditions such as the laser wavelength and power, the kind of spectrometer, the detector efficiency, etc; differ from one study to the other, which could lead to different recorded spectral region (for example, the region under $2000 \mathrm{~cm}^{-1}$ for a 780 or $785 \mathrm{~nm}$ wavelength excitation ${ }^{[3,23,28,29]}$ ), to different band shapes and/or weak features (for example the baseline subtraction in case of fluorescence ${ }^{[29]}$ ), and hence, may hampers scrupulous spectra comparison. Therefore, the characterization of a wide collection of materials using both Raman and infrared spectroscopies is here proposed. The experimental conditions for Raman investigations have been optimized to avert the strong fluorescence of some of these materials. In addition, the variation with drying/ageing of the Raman signal of one resin, colophony, is discussed. The final aim of this study is to show that the combined use of Raman and infrared spectroscopies may be an efficient technique to discriminate between organic varnish materials in a nondestructive way.

\section{Experimental}

Analyzed materials - A series of fourteen natural organic reference substances were analyzed: glues, gums, oils and natural resins; selected as having been used as varnish materials. Regarding the sealers and basecoats, three proteinaceous animal glues have been studied: rabbit skin, fish and isinglass glues, as well as arabic gum which is quite representative of the gum family. Concerning the varnish layers, five diterpenic resins (Congo copal, Manila copal, colophony, sandarac and Venice turpentine), two triterpenic (mastic and elemi) and two qualities of the insect resin shellac were

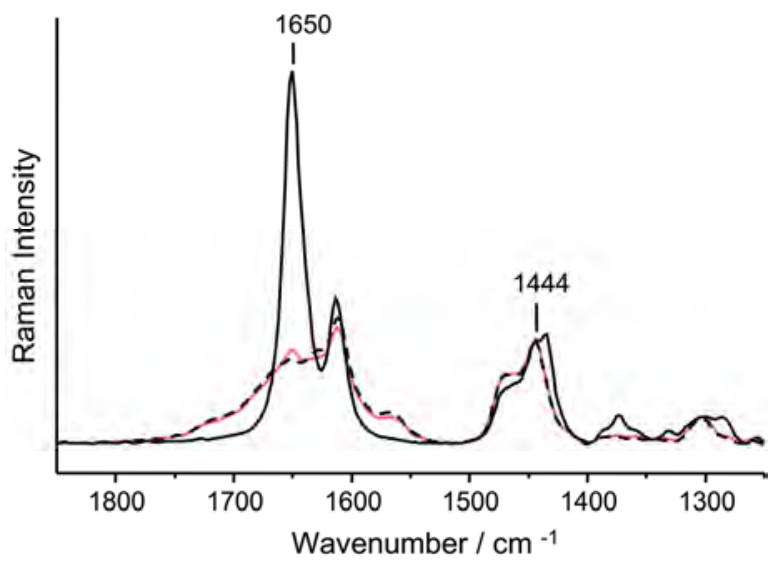

Figure 1. FT-Raman spectra of different fragments of colophony. Black solid line spectrum: internal fragment of the resin, black dashed line spectrum: aged grain, reddish solid line spectrum: colophony varnish film. analyzed (the "Platina" quality has been treated to remove most of the waxes and the colouring matters, whereas the "Cherry" quality is closer in composition to the excreted resin). Linseed oil is the most commonly used and is characteristic of the drying oils' family. The fourteen materials under study have been bought more than fifteen years ago from various suppliers (Venice turpentine and colophony from HMB, Paris France; linseed oil, Cherry and Platina shellacs from Laverdure, Paris France, and rabbit skin glue from Sennelier, Paris France), and taken from the restoration materials of the laboratory of the Musée de la Musique (Paris, France). These reference substances have been analyzed using Raman and IR spectroscopies (Table S1 Supporting Information) in their "raw" form (i.e. as commercialized: solid fragments, tears, powder, flat fragments, semiliquid, etc.) or as varnish films coated onto microscope glass slides. The varnish solutions have been prepared (in 2007) by crushing the investigated materials and dissolving them in ethanol (resin/alcohol 1:2, w/w) and coated onto the slides. According to the experimental conditions required for each technique (preferred sample shape), either of the two available forms was analyzed.

Raman spectroscopy - FT-Raman analyses were performed and presented viable spectra for all the materials. The near infrared excitation at $1064 \mathrm{~nm}$ provided by a Nd-YAG laser diode is coupled to a Bruker RFS 100/S spectrometer, based on a Michelson-type interferometer, and equipped with a liquid nitrogencooled $\mathrm{Ge}$ detector. Spectra were recorded between 3500 and $50 \mathrm{~cm}^{-1}$ with a $4 \mathrm{~cm}^{-1}$ resolution and 64 to 1024 scans to optimize counting time and the signal-tonoise ratio. A macroscopic interface equipped with a $90^{\circ}$ collecting mirror was used, to allow samples to be placed on a horizontal surface. In this configuration, the laser spot size is about $100 \mu \mathrm{m}$. Spectra were recorded with a nominal power of $500 \mathrm{~mW}(400 \mathrm{~mW}$ at the sample, no degradation due to heating was observed). Samples were placed on a gold mirror to improve the Raman signal intensity. In complement, Raman spectra have also been recorded using three excitation wavelengths in the visible light $(633,514$ and $458 \mathrm{~nm})$ using a Horiba Jobin Yvon HR 800 micro-spectrometer. Although most of the investigated materials are known to be fluorescent even under high wavelength excitation in the visible ${ }^{[30]}$, some of our samples showed Raman bands. These tests confirm that a near infrared excitation wavelength is more useful in the case of these natural organic media (Fig. S1 Supporting Information). On each raw material, several spectra were acquired at different spots of each fragment, to assess the homogeneity among the measured data. The varnish films were also analyzed, but because of the sample thinness (i.e. low amount of analyzed matter), a very weak signal-to-noise ratio and noisy features characterized the obtained spectra. Hence, these spectra, similar to the raw materials' ones, were inadequate for detailed interpretation and comparison. The presented and discussed spectra are thus the ones obtained for raw materials' fragments.

Infrared spectroscopy - Micro-infrared spectroscopy analyses were performed in transmission mode using a diamond cell on an Excalibur FTS 4000 spectrometer coupled to a UMA 600 microscope (Digilab-Varian) equipped with liquid nitrogen-cooled MCT detector. The 
varnish films were the most adapted for this set up. 128 scans were accumulated between 4000 and $400 \mathrm{~cm}^{-1}$ with a $4 \mathrm{~cm}^{-1}$ resolution.

\section{Results and discussion}

Materials homogeneity - influence of ageing on Raman spectra - For each material, spectra were collected in different areas with the same experimental conditions (for instance, in the case of solid materials, the surface of a grain and its internal part). No distinction between the spectra could be made, except in the case of colophony. Figure 1 shows spectra in the 1250$1900 \mathrm{~cm}^{-1}$ range of different fragments of colophony - a fresh one sampled from the internal part of the resin, and another one of degraded appearance - where the major spectral modifications are observed. The $1650 \mathrm{~cm}^{-1}$ band is assigned to the stretching vibration of the olefinic group $v\left(\mathrm{C}=\mathrm{CH}_{2}\right)$ and the $1444 \mathrm{~cm}^{-1}$ band to the deformation of $\mathrm{CH}$ bonds $\left(\mathrm{CH}_{2}\right.$ or $\mathrm{CH}_{3}$ groups ${ }^{[4]}$. The amount of the latter does not change significantly during ageing, so the $1444 \mathrm{~cm}^{-1}$ band was chosen for spectra intensity normalization (Fig. 1) after the subtraction of a same baseline for all spectra. The decrease of the 1650 $\mathrm{cm}^{-1}$ band is observed between the internal fragment

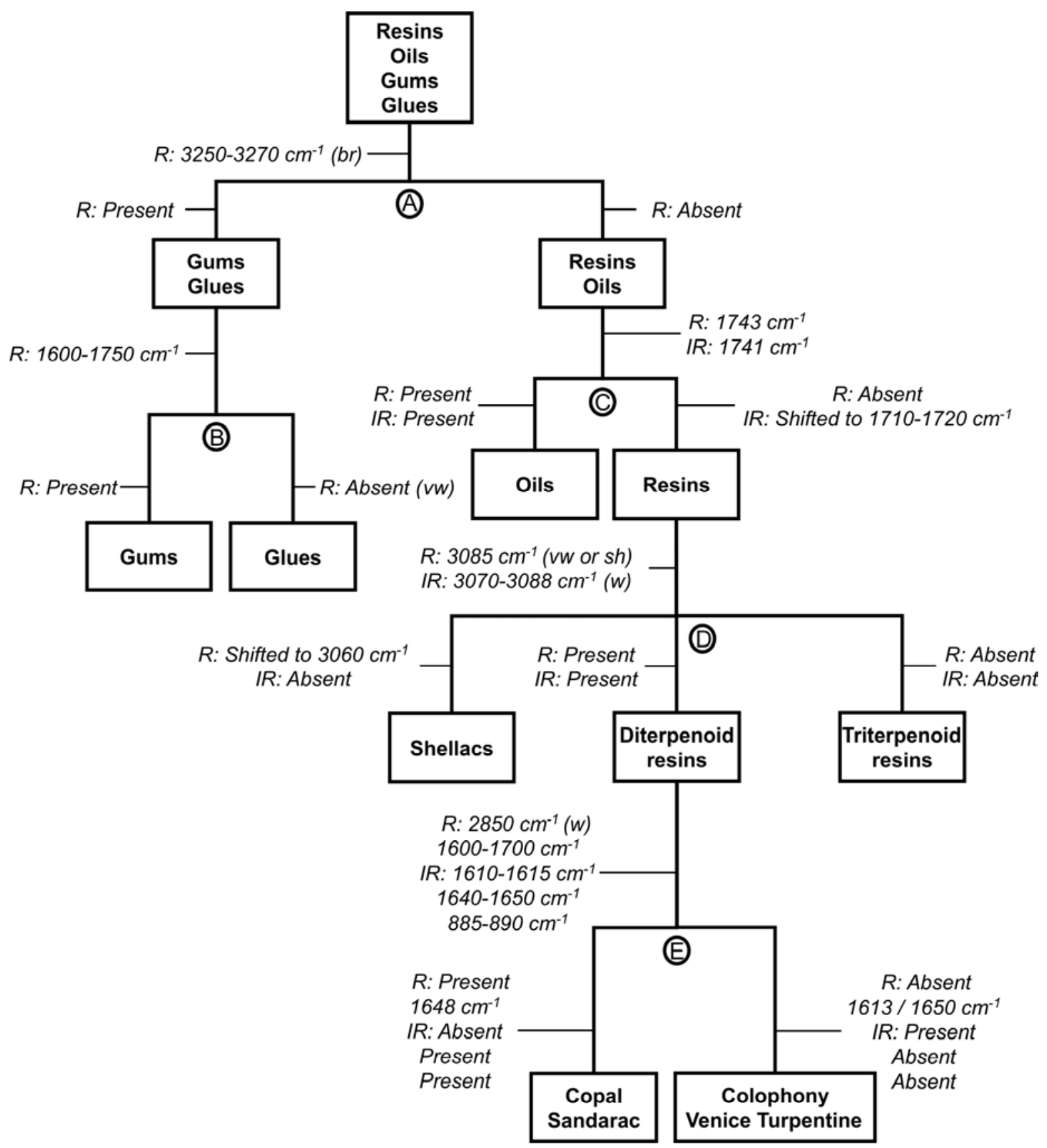

Figure 2. Flowchart that leads to the segregation of the studied materials. In italic the indications (bands present or absent on the spectra) to follow: R: Raman, IR: infrared, br: broad, w: weak, vw: very weak and sh: shoulder. The different steps (A to E) are discussed in the text. 




Figure 3. FT-Raman spectra of diterpenic resins: a) Manila copal, b) Congo copal, c) sandarac, d) colophony, and e) Venice turpentine and triterpenic resins: f) mastic, and g) elemi. The pointed bands are those chosen as criteria to build the flowchart (see text for details).

spectrum and the older fragment one. This phenomenon was attributed to polymerization and oxidation processes of the olefinic terpenoids, leading to the decrease of the $\mathrm{C}=\mathrm{CH}_{2}$ amount ${ }^{[27]}$. The evolution of the $1650 \mathrm{~cm}^{-1}$ band can be measured by the intensity ratio of the two considered bands ${ }^{[31]}$. For our samples, this ratio is of 3.98 for the fresh fragment and of 0.80 for the aged one. Other studies by IR and GC/MS measurements ${ }^{[7]}$ have discussed the oxidation processes of abietane and pimarane molecules (main skeletons of colophony). They have also suggested a polymerization phenomenon by size exclusion chromatography, which demonstrate the formation of higher molecular weight compounds. Such phenomena (oxidation and/or polymerization) might consequently have been occurring in our colophony samples. The varnish film made of colophony was also analyzed in the same conditions than the two raw fragments mentioned above. Its FTRaman spectrum (Fig. 1, reddish solid line spectrum) is very similar to the aged grain one, and the intensity ratio of the two bands is of 0.88 , of the same range as the aged grain. Oxidation and/or polymerization reactions seem also to take part in the drying/ageing of this colophony varnish.
Material discrimination through vibrational spectroscopies - Previous works carried out on the discrimination of organic binding media have been proposed using a flowchart based on IR bands ${ }^{[32]}$ or using Raman spectral features on a small corpus of resins ${ }^{[33]}$. However, the chosen features may sometimes be too weak to be used for characterization. In this study, a highlight of the spectral differences between natural organic compounds is proposed by comparing their spectra. A joint use of Raman and IR spectroscopies is used to improve the materials discrimination. In particular, a flowchart (Fig. 2), conceived after the series of FT-Raman and IR data collected, is proposed as a tool to discriminate between these natural materials by considering their spectroscopic characteristics. The chosen spectral features are simple, notable and specific; and should appear even on poor quality spectra. Indeed, analyzing small samples, typically a film of varnish on a work of art, will give less intense Raman spectra or a bad signal-tonoise ratio because of the slight quantity of matter. Thus, the following discussion is based only on the absence or presence of principal bands used as main criteria (Figs. 3 to 6 ). 


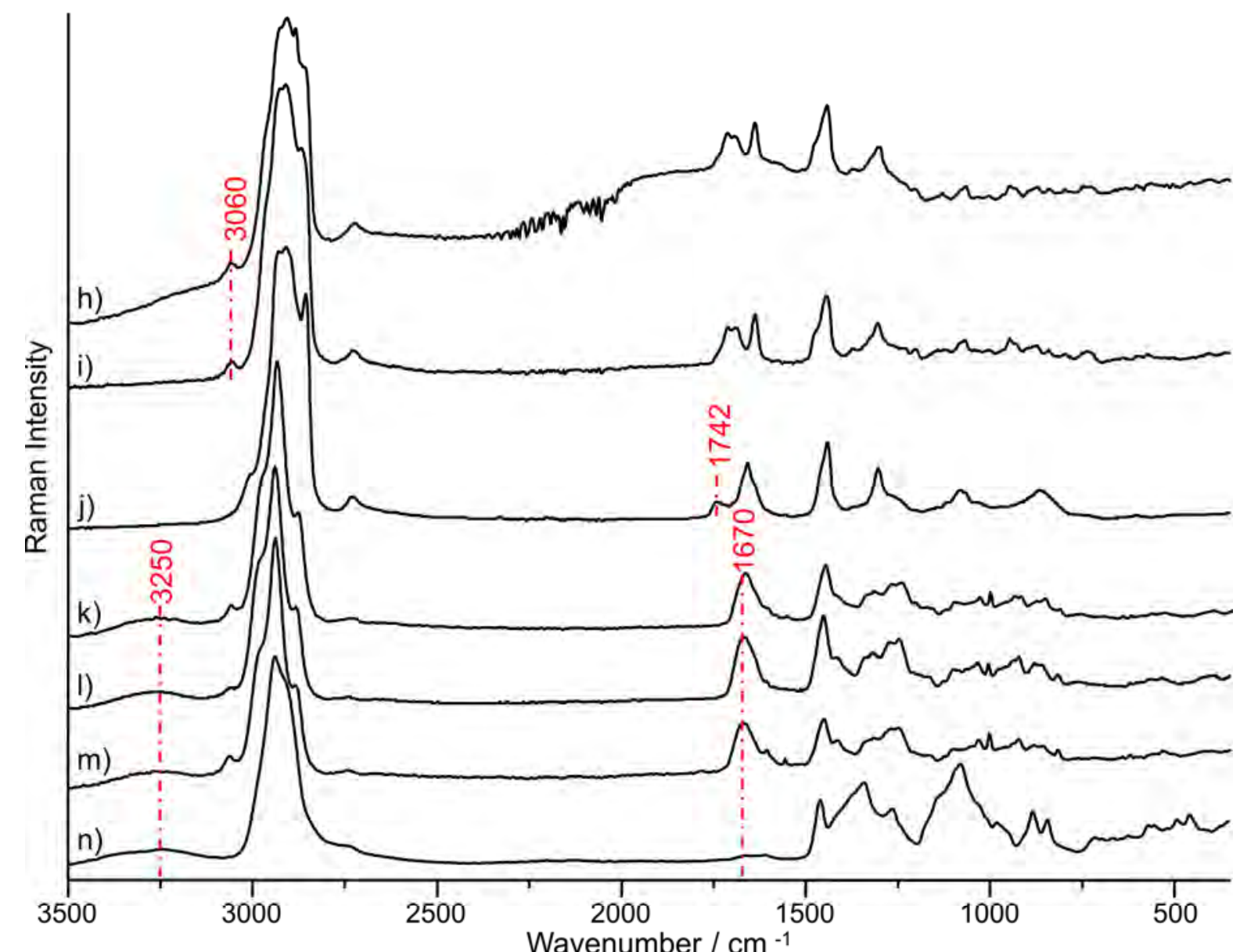

Figure 4. FT-Raman spectra of shellacs, oils, glues and gums: h) shellac "cherry", i) shellac "Platina", j) linseed oil, k) isinglass glue, I) fish glue, m) rabbit skin glue, and n) arabic gum. The pointed bands are those chosen as criteria to build the flowchart (see text for details)

Glues and gums are identified (Fig. 2 step A) by the $3250-3270 \mathrm{~cm}^{-1}$ Raman broad band (Fig. 4) assigned to the stretching vibration of the $\mathrm{OH}$ groups ${ }^{[4]}$. The Raman "massif" between 1600 and $1750 \mathrm{~cm}^{-1}$ is very weak for arabic gum, whereas it is more intense for glues (Fig. 4). This criterion can be useful to differentiate those two materials (Fig. 2 step B). The $1670 \mathrm{~cm}^{-1}$ Raman band is assigned to the $\mathrm{C}=\mathrm{O}$ stretching vibration ${ }^{[3]}$, a chemical group widespread in proteins (glues) and absent from polysaccharides (arabic gum). The linseed oil spectra show a weak Raman band (Fig. 4-j) and an intense infrared band (Fig.6-j) at $1742 \mathrm{~cm}^{-1}$ attributed to the $\mathrm{C}=\mathrm{O}$ stretching ${ }^{[3,32]}$. For the resins family, this band is shifted to $1710-1720 \mathrm{~cm}^{-1}$ on the IR spectra (Fig. 2 step C and Fig. 5). The resins can be divided into three subfamilies (within the studied corpus): shellacs, diterpenoid resins and triterpenoid resins. Shellac's Raman spectra show a band at $3060 \mathrm{~cm}^{-1}$ (Fig. 2 step D, Fig. 4-h and i) assigned to the stretching vibration of the aromatic or olefinic $\mathrm{CH}$ groups ${ }^{[4]}$. This characteristic band appears on the diterpenoid resins Raman spectra at $3085 \mathrm{~cm}^{-1}$ but is absent from the triterpenoid resins ones (Fig. 2 step $D$ and Fig. 3). It can be explained by the presence of vinyl groups in pimarane and labdane diterpenoid skeletons, which are almost absent from the mastic and elemi triterpenoids structures (oleanane and euphane) ${ }^{[5]}$. However, when this Raman band appears only as a shoulder, the IR band between 3070 and $3088 \mathrm{~cm}^{-1}$ (Fig. 5), assigned to the same group, permits to conclude. Concerning the separation of the diterpenoid resins in two groups (Fig. 2 step E), the indications must be taken as a whole and not by order of importance (Fig. 3, Fig. 6, and Figs. S2 and S3 Supporting information for more detailed spectral areas). On one hand, copal and sandarac have same major components (ex. communic acid); and, on the other hand, Venice turpentine and colophony come both from conifers (Pinaceae family) and contain isopimaric and abietic acids ${ }^{[34]}$

One more step that sets apart each diterpenic resin (copal, sandarac, Venice turpentine and colophony) may be proposed, though it is based on minor spectral features (very weak bands or shoulders). For example, a very weak band at $1715 \mathrm{~cm}^{-1}$ is present on the copal's Raman spectrum but absent from the sandarac's one (Fig. S2b Supporting Information). The $2988 \mathrm{~cm}^{-1}$ shoulder is present on Venice turpentine's Raman spectrum but absent from the colophony's one (Fig. S2a Supporting Information). Using these features for material recognition is tricky because they might not appear on poorer quality spectra.

Be that as it may, this flowchart is appropriate to identify unknown raw materials, but preferentially in the case of "modern" media because it was built on relatively "fresh" materials. Therefore, its application in case of aged or altered materials could be inconvenient since their spectra are likely to be modified, as illustrated previously with the case of colophony. Anyway, this tool can attest the presence of a specific material in a varnish mixture, by the presence on its Raman and infrared spectra of its characteristic bands. For example, the presence of a band at $3080 \mathrm{~cm}^{-1}$ on both Raman and infrared spectra 


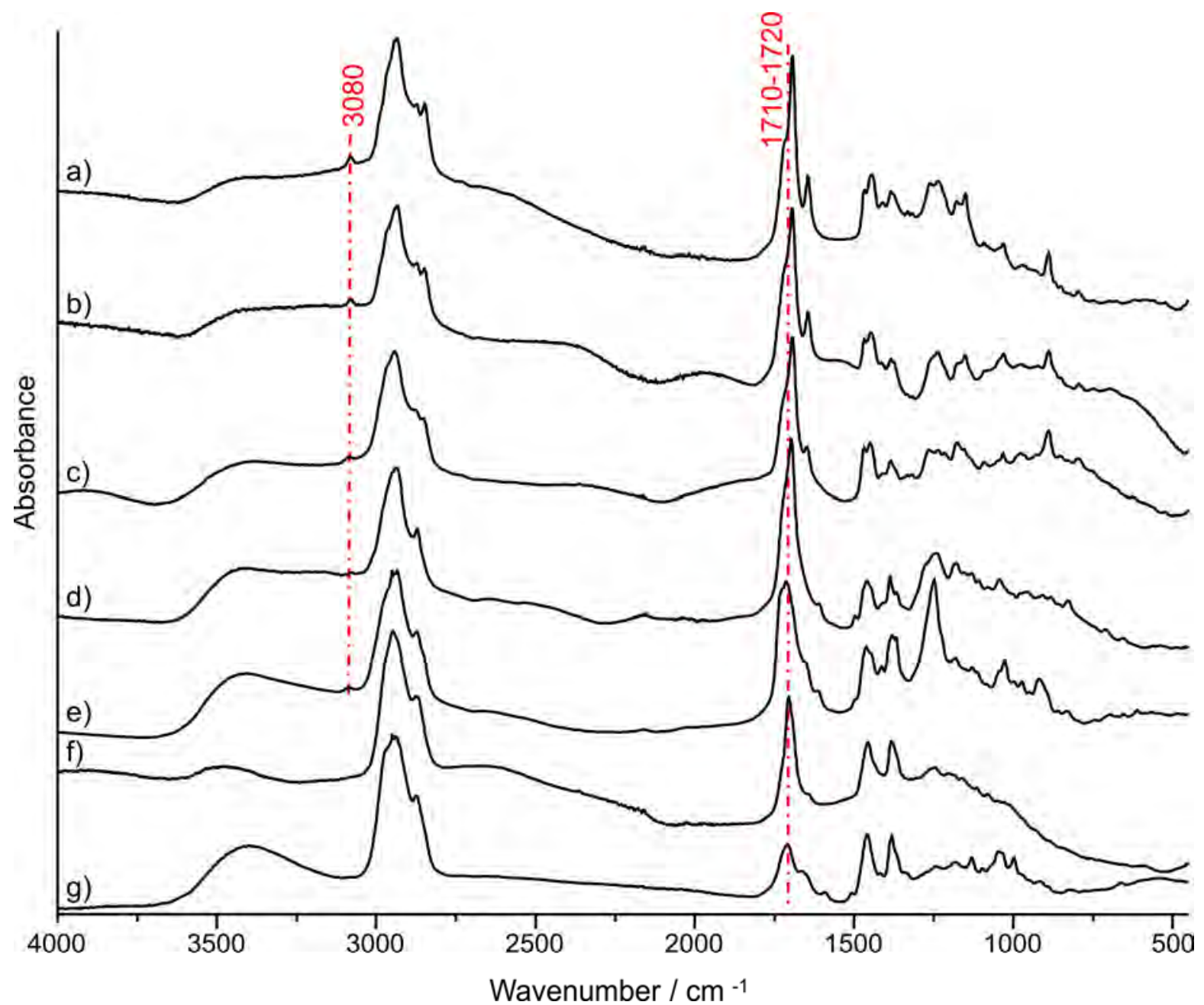

Figure 5. IR spectra of diterpenic resins: a) Manila copal, b) Congo copal, c) sandarac, d) colophony, and e) Venice turpentine and triterpenic resins: f) mastic, and g) elemi. The pointed bands are those chosen as criteria to build the flowchart (see text for details).

of a varnish will prove the presence, in the mixture, of a diterpenic resin (Fig. 3 and Fig. 5). However, such interpretations have to be carefully established because sometimes the mixture components can interfere between each others. For that, further investigations on experimental varnishes with different constituents have to be carried out, to test the robustness of the proposed discriminative flowchart.

\section{Conclusion}

Raman analyses of natural organic materials by visible and near infrared wavelengths underline that only FTRaman allows a proper collection of their Raman spectra, since it avoids totally their fluorescence emission. A set of well defined spectra of a large collection of natural organic reference substances which might be encountered as vanish materials, and representing glues, oils, gums and natural resins, were obtained. Infrared analyses in transmission were also performed on the same sample set. The combination of Raman spectroscopic features with infrared ones succeeded in building an algorithm which identify and discriminate the different media. A flowchart for material recognition is proposed: the four chemical families represented by our samples (resins, oils, glues and gums) were easily separated, and further, within the resins family, four subgroups were clearly set apart: triterpenic resins, shellacs, colophony and Venice turpentine, and finally copal and sandarac. This flowchart should be used for the determination of a varnish composition, with a main relevance for a substance presence, as mixture spectrum could mask some minor components. It could be also useful for the identification of unknown raw materials, whether they are fresh or from archaeological contexts. Another limitation would arise with degradation/ageing of these natural organic materials when their spectra are significantly modified (as underlined in this study with colophony). This work on unaged reference samples is a first step of a study in progress which is continuing on one hand, on ancient cultural heritage samples, and on the other hand, on the extension of the reference database for natural organic materials and their alterations.

\section{Acknowledgments}

Linda Berger is thanked for the preparation of the varnish films. GdR 3174 of CNRS: ChimARC "Bio-géophysico-CHIMie des ARchéomatériaux et des biens Culturels" is thanked for partly supporting this work. 


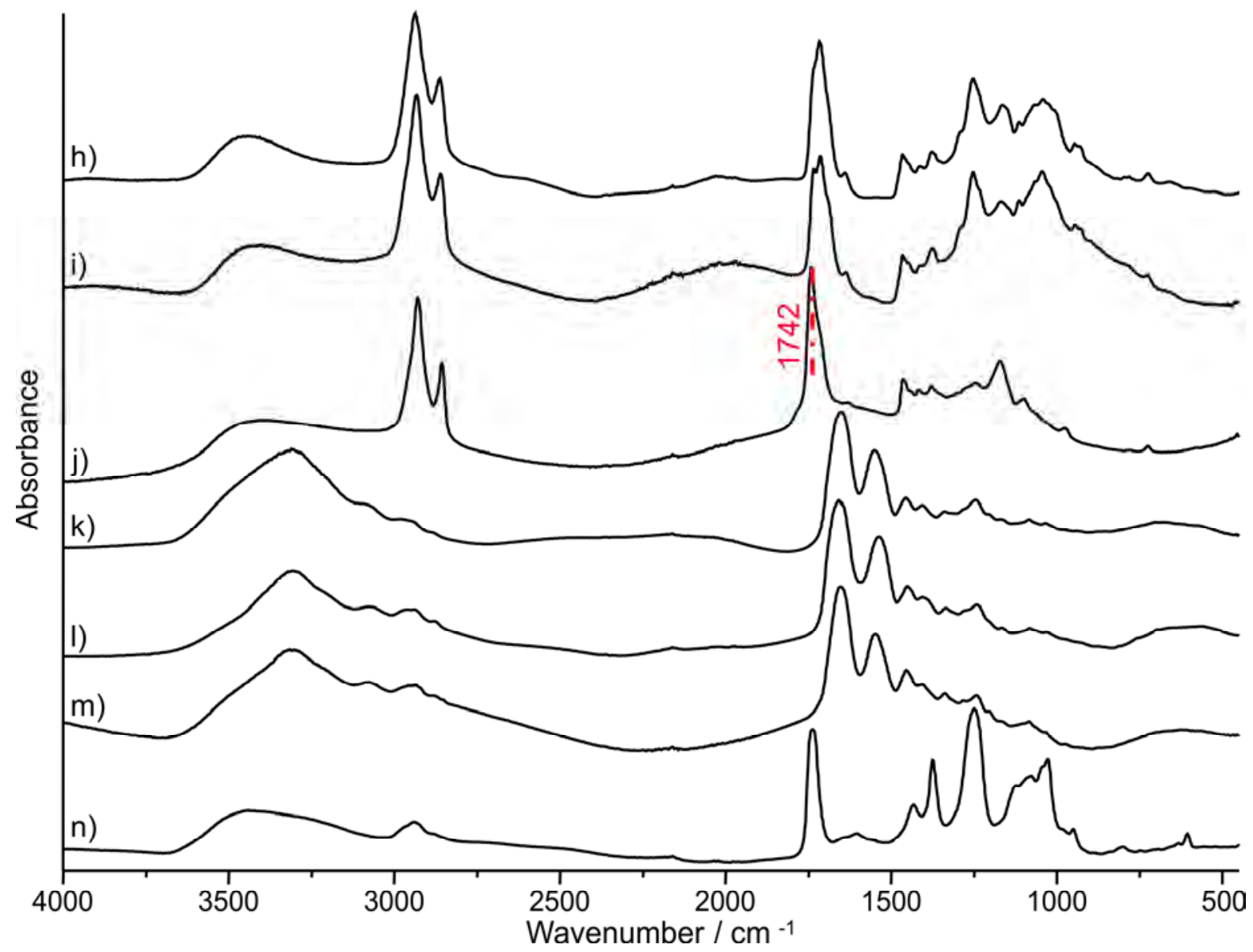

Figure 6. IR spectra of shellacs, oils, glues and gums: h) shellac "Cherry", i) shellac "Platina", j) linseed oil, k) isinglass glue, I) fish glue, $\mathrm{m}$ ) rabbit skin glue, and n) arabic gum. The pointed bands are those chosen as criteria to build the flowchart (see text for details).

\section{References}

[1] J.-P. Echard, B. Lavedrine, J. Cult. Herit. 2008; 9, 420.

[2] M. Derrick, J. Am. Inst. Conservat. 1989; $28,43$.

[3] P. Vandenabeele, B. Wehling, L. Moens, H.G.M. Edwards, M. De Reu, G. Van Hooydonk, Anal. Chim. Acta 2000; 407, 261.

[4] H.G.M. Edwards, D.W. Farwell, L. Daffner, Spectrochim. Acta, Part A 1996; 52, 1639.

[5] J.S. Mills, R. White, The Organic Chemistry of Museum Objects, $2^{\text {nd }}$ ed., Butterworth - Heinemann, 1994.

[6] J. Mallégol, J.L. Gardette, J. Lemaire, J. Am. Oil Chem. Soc. 2000; 77, 257.

[7] D. Scalarone, M. Lazzari, O. Chiantore, J. Anal. Appl. Pyrolysis 2002; 64, 345

[8] D. Scalarone, M. Lazzari, O. Chiantore J. Anal. Appl. Pyrolysis 2003; 68-69, 115

[9] M.T. Domenech-Carbo, L. Osete-Cortina, J.D. Canizares, F. Bolivar-Galiano, J. Romero-Noguera, M.A. FernandezVivas, I. Martin-Sanchez, Anal. Bioanal. Chem. 2006; 385, 1265.

[10] M. Regert, V. Alexandre, N. Thomas, A. Lattuati-Derieux, J. Chromatogr., A 2006; 1101, 245.

[11] R.J. Stacey, C.R. Cartwright, C. McEwan, Archaeometry 2006; 48, 323

[12] J.-P. Echard, C. Benoit, J. Peris-Vicente, V. Malecki, J.V. Gimeno-Adelantado, S. Vaiedelich, Anal. Chim. Acta 2007; 584, 172.

[13] D. Scalarone, J. van der Horst, J.J. Boon, O. Chiantore, J. Mass Spectrom. 2003; 38, 607

[14] M. Regert, T. Devièse, A.-S. Le Hô, A. Rougeulle, Archaeometry 2008; 50, 668.

[15] J.-P. Echard, S. Vaiedelich, in De la peinture de chevalet à l'instrument de musique: vernis, liants et couleurs; Cité de la musique, Paris, 2008

[16] J. Pilc, R. White, NG Tech. Bull. 1995; 16, 73.
[17] R. White, J. Kirby, NG Tech. Bull. 2001; 22, 64

[18] J.-P. Echard, M. Cotte, E. Dooryhee, L. Bertrand, Appl. Phys. A: Mater. Sci. Process. 2008; 92, 77.

[19] G. Cartoni, M.V. Russo, F. Spinelli, F. Talarico, Annali Di Chimica 2003; 93, 849.

[20] J.-P. Echard, L. Bertrand, A. von Bohlen, A.-S. Le Hô, C. Paris, L. Bellot-Gurlet, B. Soulier, A. Lattuati-Derieux, S. Thao, L. Robinet, B. Lavédrine, S. Vaiedelich, Angew. Chem., Int. Ed. 2010; 49, 197.

[21] M.P. Colombini, G. Giachi, F. Modugno, P. Pallecchi, E. Ribechini Archaeometry 2003; 45, 659.

[22] L. Burgio, R.J.H. Clark, Spectrochim. Acta, Part A 2001; 57, 1491.

[23] H.G.M. Edwards, M.J. Falk, J. Raman Spectrosc. 1997; 28, 211.

[24] G.D. Smith, R.J.H. Clark, J. Archaeol. Sci. 2004; 31, 1137.

[25] H.G.M. Edwards, J.M. Chalmers, Raman Spectroscopy in Archaeology and Art History, Royal Society of Chemistry, 2005.

[26] W. Winkler, E.Ch. Kirchner, A. Asenbaum, M. Musso, J. Raman Spectrosc. 2001; 32, 59.

[27] P. Vandenabeele, D.M. Grimaldi, H.G.M. Edwards, L. Moens, Spectrochim. Acta, Part A 2003; 59, 2221.

[28] P. Vandenabeele, M. Ortega-Aviles, D.T. Castilleros, L. Moens, Spectrochim. Acta, Part A 2007; 68, 1085.

[29] A. Nevin, J.-P. Echard, M. Thoury, D. Comelli, G. Valentini, R. Cubeddu, Talanta 2009; 80, 286

[30] R.H. Brody, H.G.M. Edwards, A.M. Pollard, Spectrochim. Acta, Part A 2001; 57, 1325.

[31] M. Derrick, S.C. Stulik, J.M. Landry, Infrared Spectroscopy in Conservation Science, Getty Trust Publications, Getty Conservation Institute, 1999.

[32] R.H. Brody, H.G.M. Edwards, A.M. Pollard, Biopolymers 2002, 67, 129 .

[33] J.H. Langenheim, Plant Resins: Chemistry, Evolution, Ecology, and Ethnobotany, Timber Press, 2003. 


\section{Supplementary Information}

\begin{tabular}{|c|c|c|c|c|c|}
\hline $\begin{array}{c}\text { Chemical } \\
\text { Composition }\end{array}$ & Material & \multicolumn{2}{|c|}{ Description } & IR analyses & Raman analyses \\
\hline \multirow{10}{*}{ Diterpenoids } & \multirow{2}{*}{ Congo copal } & Raw & Grain & \multirow[b]{2}{*}{$\mathbf{X}$} & \multirow{2}{*}{$\begin{array}{l}X \\
X \\
\end{array}$} \\
\hline & & & arnish & & \\
\hline & \multirow{2}{*}{ Manila copal } & Raw & Grain & \multirow[b]{2}{*}{$\mathrm{X}$} & $\mathbf{X}$ \\
\hline & & \multicolumn{2}{|c|}{ Varnish } & & $\mathbf{X}$ \\
\hline & \multirow{2}{*}{ Colophony } & Raw & Grain & \multirow[b]{2}{*}{$X$} & $\mathbf{X}$ \\
\hline & & \multicolumn{2}{|c|}{ Varnish } & & 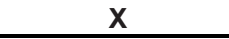 \\
\hline & \multirow{2}{*}{ Sandarac } & Raw & Grain & \multirow[b]{2}{*}{$\mathbf{X}$} & $\mathbf{X}$ \\
\hline & & & arnish & & $X$ \\
\hline & \multirow{2}{*}{ Venice turpentine } & Raw & Sticky liquid & \multirow[b]{2}{*}{$X$} & \multirow[t]{2}{*}{$\mathbf{X}$} \\
\hline & & & arnish & & \\
\hline \multirow{4}{*}{ Triterpenoids } & \multirow{2}{*}{ Elemi } & Raw & Grain & \multirow[b]{2}{*}{$\mathbf{X}$} & $\bar{x}$ \\
\hline & & & arnish & & $X$ \\
\hline & \multirow{2}{*}{ Mastic } & Raw & Grain & \multirow[b]{2}{*}{$\mathbf{X}$} & \multirow[t]{2}{*}{$\mathbf{X}$} \\
\hline & & & arnish & & \\
\hline \multirow{4}{*}{$\begin{array}{l}\text { Acids, colouring } \\
\text { matter and waxes }\end{array}$} & \multirow{2}{*}{ Shellac (Platina)* } & Raw & Flat fragments & \multirow[b]{2}{*}{$\mathrm{X}$} & \multirow[t]{2}{*}{$\mathbf{X}$} \\
\hline & & & arnish & & \\
\hline & \multirow{2}{*}{ Shellac (Cherry)* } & Raw & Solid fragment & \multirow[b]{2}{*}{$X$} & \multirow[t]{2}{*}{ X } \\
\hline & & & arnish & & \\
\hline \multirow{6}{*}{$\begin{array}{l}\text { Proteinaceous } \\
\text { media }\end{array}$} & \multirow{2}{*}{ Rabbit skin glue } & Raw & Grain & \multirow[b]{2}{*}{$\mathrm{X}$} & $\mathbf{X}$ \\
\hline & & & arnish & & \\
\hline & Fish glue & Raw & 1 & & \\
\hline & (1) & & arnish & $X$ & $X$ \\
\hline & Isinglass alue & Raw & 1 & & \\
\hline & 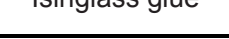 & & arnish & $\mathrm{X}$ & 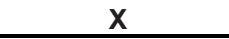 \\
\hline Polysaccharides & Arabic qum & Raw & Grain & & $\mathbf{X}$ \\
\hline & & & arnish & $X$ & $X$ \\
\hline Triqlycerides & Linseed oil & Raw & Liquid & & $\mathbf{X}$ \\
\hline & & & arnish & $\mathbf{X}$ & $X$ \\
\hline
\end{tabular}

Table S1. List of the studied materials with their chemical composition, their aspect and the different analyses that were performed. $\mathrm{X}$ : Performed analyses, *: commercial names (Laverdure).

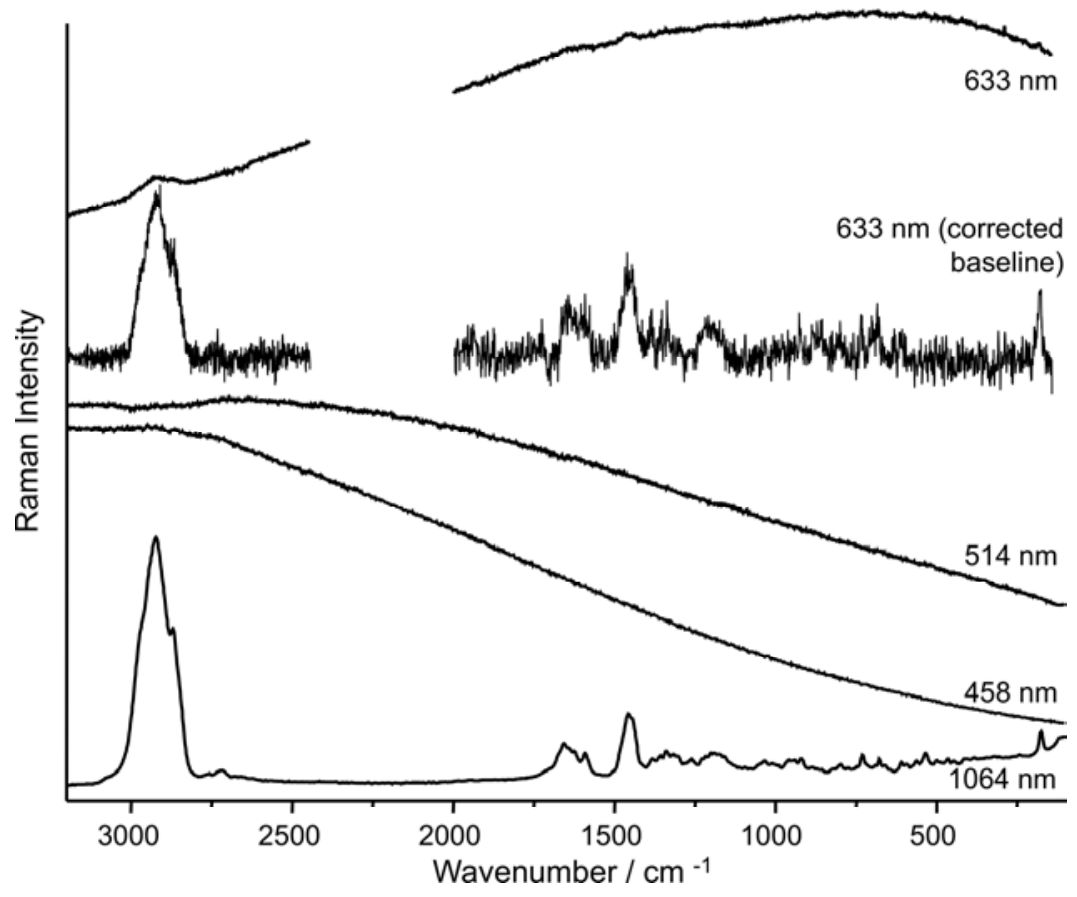

Figure S1. Raman spectra of elemi with different excitation wavelengths. This figure is an example of the ability of FTRaman analyses to give viable data. Indeed, the corrected baseline spectrum of elemi recorded with a $633 \mathrm{~nm}$ laser excitation reveals some Raman bands but the poor signal-to-noise ratio led to deteriorated band shapes and weak features. The different materials that show a Raman signal with visible wavelength excitations are the following: Congo copal (633, 514 and $458 \mathrm{~nm})$, Manila copal (633 and $514 \mathrm{~nm})$, colophony $(633 \mathrm{~nm})$, sandarac $(633 \mathrm{~nm})$, Venice turpentine (633 and $458 \mathrm{~nm})$, mastic (633 and $458 \mathrm{~nm}$ ) and finally arabic gum (633 nm); while fluorescence emission completely hid the Raman signal for the others. For such organic media, a near infrared excitation wavelength is useful in order to improve the (Raman signal)/(fluorescence signal) ratio. 


\section{Supplementary Information}

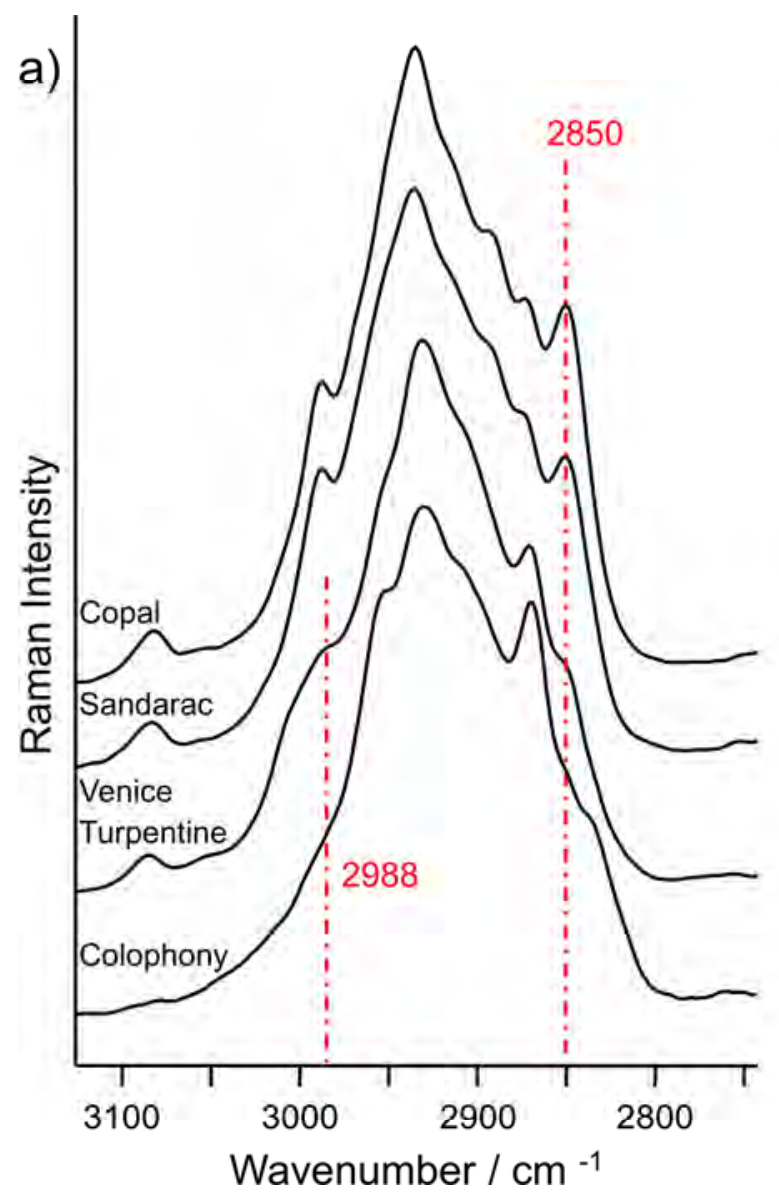

b)

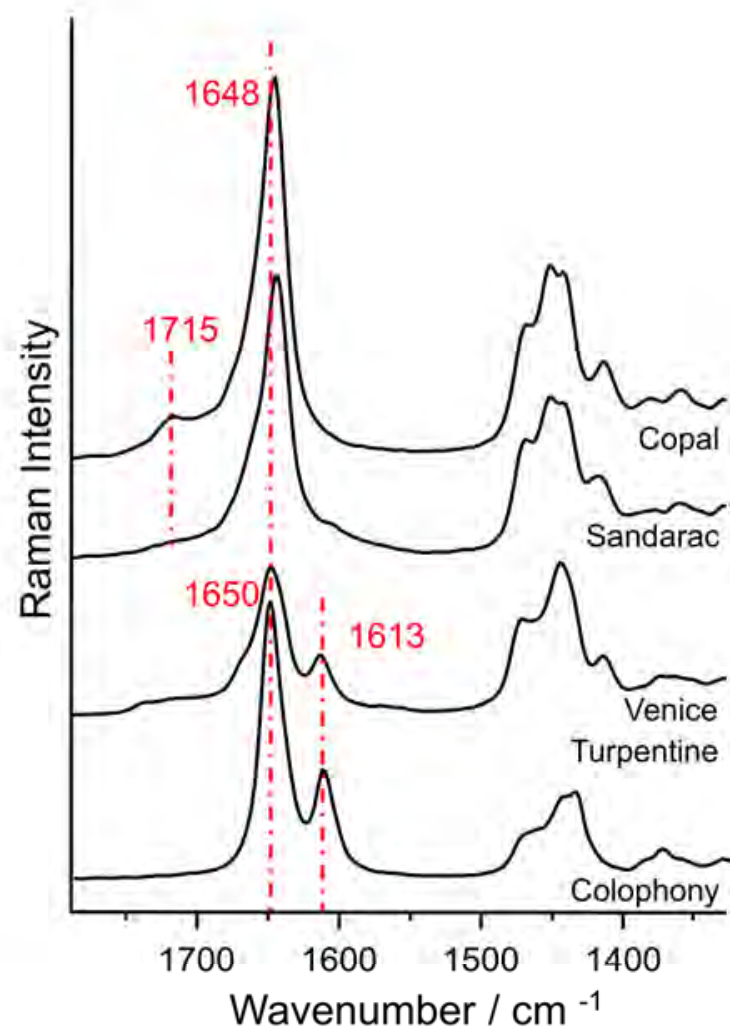

Figure S2. Detailed areas of the diterpenoid resins' FT-Raman spectra. The pointed bands are those chosen to separate the two groups of diterpenoids (see text for details). a) region between 3200 and $2750 \mathrm{~cm}^{-1}, \mathrm{~b}$ ) region between 1800 and $1350 \mathrm{~cm}^{-1}$.

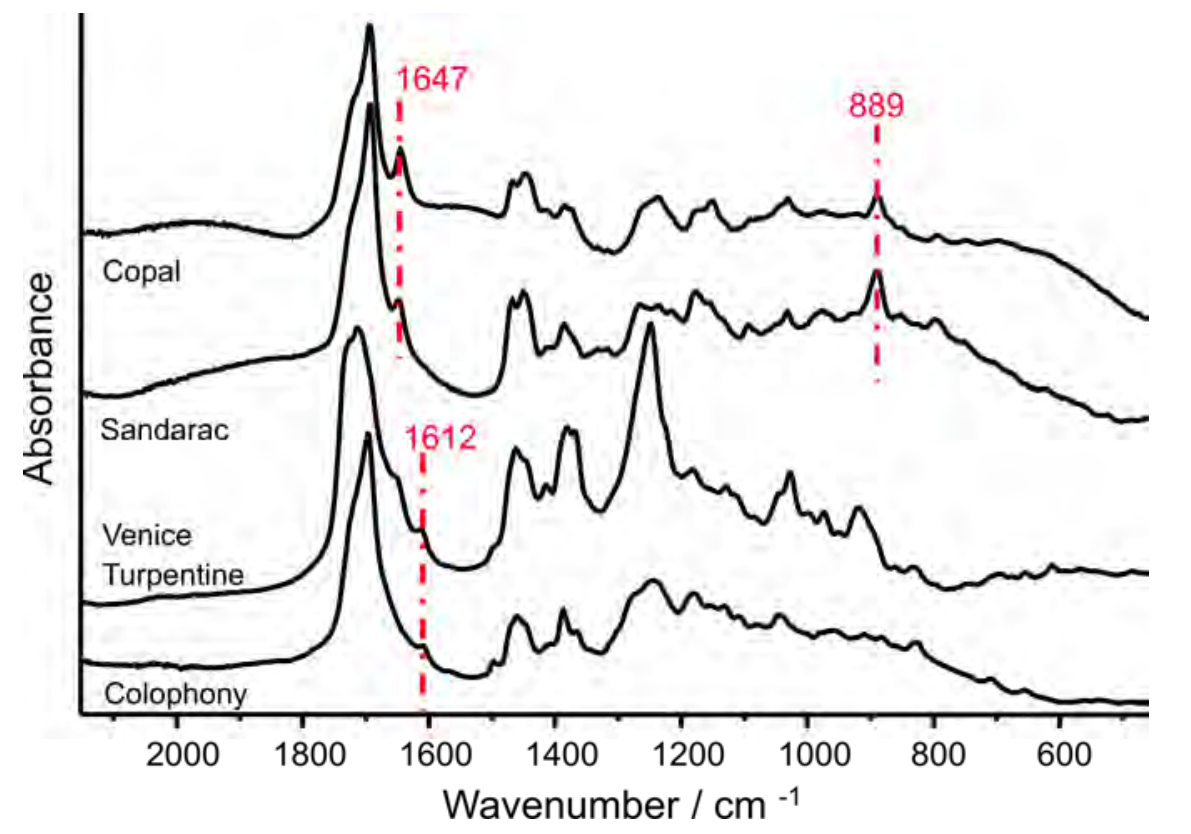

Figure S3. Detailed area of the diterpenoid resins' IR spectra (between 2500 and $500 \mathrm{~cm}^{-1}$ ). The pointed bands are those chosen to separate the two groups of diterpenoids. 